\title{
Supremo Tribunal Federal: aprimoramento das funções da Justiça E GOOD GOVERNANCE
}

Supreme Federal Court: amelioration of the justice functions and good governance

\section{Antonio César Bochenek}

Doutor em Direito, Justiça e Cidadania no século XXI pela Universidade de Coimbra. Juiz Federal do Tribunal Regional Federal da 4 a Região. Presidente da Associação Paranaense dos Juízes Federais (APAJUFE). Professor da Escola da Magistratura Federal do Paraná. Professor e Coordenador do Grupo de Pesquisas em Direito do CESCAGE.

\section{Vinicius Dalazoana}

Pós-graduando em Direito Tributário pela Fundação Getúlio Vargas - Escola de São Paulo. Pesquisador vinculado à Academia Brasileira de Direito Constitucional, no projeto "Teoria Constitucional Contemporânea: Aspectos Controvertidos".

RECEBIDO EM: 19.04 .2013

APROVADO EM: 12.06 .2013

\section{Resumo}

Os sistemas judiciais, no Brasil e em todo o mundo, estão passando por grandes modificações nas últimas décadas. No Brasil, de modo especial após a Constituição Federal de 1988, verifica-se um importante aumento da judicialização das relações sociais e da política. Além disso, a função judicial tem hoje uma relevante relação com as funções administrativas dos tribunais. Assim, uma satisfatória prestação jurisdicional requer também boas práticas administrativas. Nesse sentido, aumenta progressivamente o número de estudos sobre conceitos e técnicas de "good governance" nos assuntos públicos. Nesse artigo, sustenta-se que a nova compreensão do modelo de justiça necessita da implementação de técnicas e práticas de good governance nos tribunais, principalmente relacionadas às ideias de responsabilidade, transparência, participação, eficácia, eficiência e coerência. 
Palavras-chave: Supremo Tribunal Federal. Funções da Justiça. Good GoverNANCE.

\begin{abstract}
The judicial systems, in Brazil and in the whole world, are passing by great modifications in the latest decades. In Brazil, especially after 1988 Federal Constitution, it is verified an important increase in the judicialization of social relations and politics. Besides, the judicial function has nowadays a relevant relation with the administrative functions of the courts. Therefore, a satisfactory jurisdictional installment requires also good administrative practices. In this sense, the number of studies about good governance concepts and techniques in the public subjects is progressively increasing. In this paper, it is backed that the new comprehension of the justice model necessitates of the good governance techniques and practices implementation in the courts, mainly the ones related with the responsibility, transparency, participation, efficacy, efficiency and coherency ideas.
\end{abstract}

Key-words: Supreme Federal Court. Justice Functions. Good Governance.

SuMÁRIo: Introdução. 1. O aprimoramento das funções da justiça, o STF e good governance. 2. Tribunais supranacionais e resolução alternativa de conflitos. 3. Os princípios da good governance. 3.1 Transparência. 3.2 Responsabilidade. 3.3 Participação. 3.4 Coerência. 3.5 Eficácia e eficiência. 3.5.1 Repercussão geral. 3.5.2 Súmula vinculante. Conclusões. Referências.

\title{
INTRODUÇÃo
}

Os sistemas judiciais ao redor do mundo passaram por transformações, assim como ocorreu, e ainda ocorre no Brasil. As reformas e as alterações promovidas até o momento não são suficientes, contudo, para responder satisfatoriamente às principais dificuldades e obstáculos relacionados à eficiência da prestação jurisdicional.

Ao lado das crises, reformas e aprimoramentos dos sistemas judiciais, aumentam os estudos sobre conceitos e técnicas de "good governance" nos assuntos públicos, inclusive no poder judiciário. As boas práticas e a excelência nos serviços prestados pelo sistema judicial são pontos cruciais para o aprimoramento das funções da justiça. A nova compreensão do modelo de justiça passa pela implementação de técnicas e práticas de good governance nos tribunais, principalmente relacionados às ideias de responsabilização, transparência, participação, eficácia, eficiência e 
coerência.

Assim, no que respeita ao sistema judicial, novos caminhos são abertos ou reabertos. A coesão e a pacificação social não consistem mais em monopólios do Estado e a as funções da justiça passam a ser compartilhadas com outras forças (internacionais e atores privados) e níveis (local, regional, global). É preciso verificar em que medida os meios alternativos de resolução de litígios na esfera judicial (juizados especiais), ou extrajudicial (mediação, arbitragem), e de outras instâncias judiciais a nível internacional (tribunais supranacionais), incrementam ou complementam os sistemas judiciais nacionais.

As respostas e soluções às indagações não são simples. O presente texto não pretende esgotar o tema, mas trazer contributos para o aprimoramento e a excelência da prestação jurisdicional, sob a perspectiva das recentes formas de condução dos assuntos públicos, ou seja, das novas práticas e técnicas da chamada good governance.

\section{O APRIMORAMENTO dAS FUnÇÕES dA JUSTIÇA, O STF E GOOD GOVERNANCE}

O STF desempenha um papel central dentro da estrutura judiciária brasileira. Suas decisões refletem-se diretamente sobre os atos dos poderes constituídos e a vida dos cidadãos. Embora a função típica do STF e dos tribunais seja julgar, também desempenham relevantes funções administrativas. Juízes e ministros empregam grande parte do seu tempo de trabalho com questões administrativas, principalmente quanto à condução dos processos judiciais, à divisão do trabalho entre seus membros, à divisão estrutural e material dos seus recursos. A administração judicial repercute direta e indiretamente na atividade judicante. Assim, existe uma estreita ligação entre as funções judiciais e administrativas, que necessitam, portanto, de uma coordenação para êxito da prestação jurisdicional.

As sociedades contemporâneas, com um poder centralizado, não conseguem responder, satisfatoriamente, ao conjunto cada vez mais complexo e crescente de demandas oriundas ou constituídas no sistema social, em face da impossibilidade de gerar um conjunto unitário de respostas dotadas de racionaldiade e coerência. ${ }^{132}$ A dinâmica social empreende forças a outros órgãos e instituições públicas ou da sociedade civil, que, ao lado do Estado, podem atender às expectativas dos cidadãos. As novas formas de condução responsável dos assuntos públicos e do judiciário (good governance), antes reservadas exclusivamente à esfera estatal, são cada vez mais compartilhadas e também devem ser integradas no âmbito de atuação do poder judiciário e no Supremo Tribunal Federal.

$\mathrm{O}$ conceito de good governance apresenta uma arquitetura complexa. ${ }^{133}$ As

132 CANOTILHO, J. J. Gomes. Direito Constitucional e teoria da Constituição. $7^{\text {a }}$ ed. Coimbra: Almedina. 2003, p. 1348.

133 KOENIG-ARCHIBUGI, Mathias. Mapping Global Governance. In: Governing Global- 
características comuns são o incremento da aplicação de diversas técnicas de gestão e de formas indiretas (regulações) de condução dos assuntos públicos, além da participação de atores públicos e privados e da combinação de níveis institucionais (global, regional, nacional, local). ${ }^{134} \mathrm{~A}$ proposta visa transformar os princípios clássicos com métodos modernos de gestão, e pauta-se na abertura para a participação do maior número de atores na tomada de decisões, no combate à opacidade e à inoperatividade das organizações de poder, na responsabilização, transparência e coerência, sem esquecer-se das eventuais e possíveis consequências das atuais decisões para as gerações futuras. ${ }^{135}$

A boa governância requer modos de unir as esferas da vida (político, científico, econômico, jurídico) por diferentes redes de conexão e interação, enquanto mantêm sua autonomia social. Há, ainda, um imenso vácuo na sociedade entre os espaços não ocupados ou sub-ocupados e os cidadãos, principalmente quanto às questões de igualdade de gênero, direitos humanos, meio ambiente e minorias, que precisam ser debatidas pelo poder judiciário ou atendidas pela participação da sociedade civil. Novos atores não estatais ou supranacionais ${ }^{136}$ muitas vezes estão mais próximos da situação e têm preenchido as lacunas com respostas que proporcionam

ization. Power, authority and global governance. HELD, David; McGREW, Anthony (orgs.). Cambridge: Polity Press, 2005, p. 60-63. Sobre a relativa indefinição do conceito, ver GIESEN, Klaus-Gerd. The post-national constellation: Habermas and "the second modernity". Res Public. A journal of legal and social philosophy. $\mathrm{n}^{\circ} 10,2004, \mathrm{p} .8$.

134 Canotilho defende que a good governane significa, numa compreensão normativa, a condução responsável dos assuntos do Estado em todas as esferas, governo/administração, legislativo e judiciário. Acentua a interdependência internacional dos Estados, colocando as questões de governo como problema de multilateralismo dos Estados e de regulações internacionais. Recupera ainda algumas dimensões do gerenciamento público e insiste em questões policamente fortes como as da governabilidade, da responsabilidade e da legitimação. CANOTILHO, J. J. Gomes. Brancosos e interconstitucionalidade: itinerários dos discursos sobre a historicidade constitucional. Coimbra: Almedina, 2006, p. 327. Ver também: SAND, Inger-Johanne. Polycontextuality as an alternative to constitutionalism. In: Transnational Governance and Constitutionalism. Christian Joerges, Inger-Johanne Sand and Gunther Teubner (eds.). Oxford and Portland Oregon: Hart Pbulishing, 2004, p. 44.

135 Sobre a definição de governance: ROSENAU, James N. Governance in a New Global Order. In: Governing Globalization. Power, authority and global governance. HELD, David; McGREW, Anthony (eds.). Cambridge: Polity Press, 2005, p. 71-73. LAKE, David A.; KAHLER, Miles. Governance in a Global Economy. Political Authority in Transition. Woodstock: Princeton University Press, 2003, 3-15. MAYNTZ, Renate. La teoria della governance: sfide e prospettive. Rivista Italiana di Scienza Política. $\mathrm{n}^{\circ}$ 1. 1999, p. 4. BOGASON, Peter; MUSSO, Juliet A. The Democratic Prospects of Network Governance. American Review of Public Administration. ${ }^{\circ}$ 36. 2006. pp. 3-18., p. 7.

136 Sobre os novos atores ver: WOODS, Ngaire. Global Governance and the role of institutions. In: Governing Globalization. Power, authority and global governance. HELD, David; McGREW, Anthony (eds.). Cambridge: Polity Press. 2005. pp. 26-29. 
contentamento, ganhando destaque no cenário da prevenção, pacificação e resolução de conflitos. A cooperação e a interação dialógica entre a rede de novos atores na direção dos assuntos antes reservados ao poder judiciário representa e implementa a nova forma de direção - a good governance.

A adoção das idéias de boa governância ${ }^{137}$ no âmbito dos Tribunais é acelerada pelo declínio da confiança e da credibilidade do poder judiciário junto à sociedade, e reforçada pela concepção de que o sistema de resolução dos conflitos não pode ser exclusivo do Estado. ${ }^{138}$ São diversos os motivos que desencadearam este processo: a falta de eficácia e de eficiência dos sistemas de direção estatal (judiciário), ${ }^{139}$ a aparente inefetividade das decisões judiciais, a sobrecarga do Estado, ${ }^{140}$ a perpetuação de processos ortodoxos (rotinas redundantes) e o distanciamento dos órgãos judiciários em relação à sociedade.

Contudo, o poder judiciário ainda é relevante e necessário para o sistema estatal e o STF é indispensável para a ligação entre os sistemas político e jurídico. Por outro lado, também é correto dizer que parte das atribuições judiciais e significativas parcelas de suas competências são repassadas ou delegadas para outros níveis de resolução de conflitos (tribunais supranacionais ou para os atores não judiciais, de setores privados, por meio de mediação, arbitragem, entre outros). ${ }^{141}$

Na rede de interações e nos múltiplos níveis de constitucionalismo, ${ }^{142}$ tam-

137 A expressão good governance é traduzida, em regra, como "boa governação" (Tratado Constitucional da União Europeia - Tratado de Nice), ou "boa governança” (Livro Branco da Comissão Europeia sobre governança europeia (COM. (428) final, de 25 de julho de 2001) De acordo com Aragão a melhor tradução seria "boa governância". A opção por "governância" está na linha de vocábulos de origem latina que em português mantêm a terminação "ância", que exprime a idéia de ação ou resultado de uma ação. Representa uma nova resposta para novas preocupações, ou seja, uma solução diferente para problemas especiais. (ARAGÃO, Alexandra. A governância na Constituição Européia: uma oportunidade perdida? In. Colóquio ibérico: Constituição Européia - homenagem ao doutor Francisco Lucas Pires. Coimbra: Coimbra Editora. 2005. pp. 105-107.)

138 BOGASON, Peter; MUSSO, Juliet A. The Democratic Prospects of Network Governance. In: American Review of Public Administration. $\mathrm{n}^{\circ}$ 36. 2006. pp. 3-18.

139 ARAGÃO, Alexandra, Op. cit., p. 109.

140 CANOTILHO, J. J. Gomes. Direito..., cit., p. 1348.

141 Sobre atores não judiciais que participam do processo de resolução de conflitos ver: SWEET, Alec Stone. The Judicial Constrution of Europe. Oxford: Oxford University Press. 2004.

142 Com a transferência de atribuições e competências do Estado para outras instituições da sociedade civil, a nível local, regional e supranacional, as constituições também restaram enfraquecidas dentro do contexto global. Representa os mútiplos níveis de constitucionalismo e o processo de integração por meio de redes entre as Constituições. "Como se vê, a good governance não é uma constituição nacional, supranacional ou global. Talvez se possa dizer que é um novo princípio estruturante, multilevel constituonalism”. CANOTILHO, J. J. Gomes. "Brancosos"..., cit., p. 333. 
bém o poder judiciário deve coordenar e interagir com as demais esferas de resolução de conflito. O monopólio sobre a legitimidade do poder precisa ser compartilhado com outras autoridades legitimadas que contribuam para a segurança da ordem, a pacificação e prevenção dos conflitos e participem da regulação econômica e social. ${ }^{143}$

\section{TRIBUnaIS SUPRANACIONAIS E RESOlUÇão ALTERNATIVA DE CONFLITOS}

As questões jurídicas têm sido submetidas com mais frequência aos tribunais supranacionais. São vários os motivos dessa procura: a necessidade de as diversidades serem apreciadas dentro do contexto global; as ofensas aos direitos humanos e fundamentais, muitas vezes ignoradas ou não reprimidas pelos sistemas nacionais; a reunião dos países em blocos, inicialmente econômicos, que inevitavelmente convergem para a criação de tribunais comunitários; organismos internacionais criam regulações universalizáveis sobre áreas específicas (OMC/GATT - direito comercial e aduaneiro; OIT - direto do trabalho; ONU - segurança, mercado financeiro) que transcendem o espaço geográfico dos Estados; entre outros fatores que poderiam ser arrolados.

Note-se que o próprio Estado, por meio de tratados, transfere parcela de sua atribuição para órgãos supranacionais de resolução de conflitos. Paulatinamente, portanto, é aumentada a criação desses órgãos de revisão, na tentativa de criar um mecanismo semelhante ao encontrado no âmbito doméstico. ${ }^{144}$

Dessa forma, é possível a ocorrência de fricções entre o direito interno e as diferentes concepções da jurisprudência dos tribunais supranacionais, na medida em que convivem no mesmo espaço tribunais estatais e os tribunais supranacionais. Nesse processo dialógico, as decisões dos tribunais supranacionais refletem nas decisões e políticas do direito interno dos Estados, assim como influenciam a governância democrática. ${ }^{145}$

Os sinais de tensão entre common law e civil law são múltiplos. As divergências entre o direito do Reino Unido e as normas do Tratado da União

143 SENARCLENS, Pierre de. Mondialization, Souveraineté et Théories des Relations Internationales. Paris: Armand Colin. 1998. pp. 199-201.

144 ALTER, Karen J. Private litigants and the new international courts. Comparative Political Studies. $n^{\circ}$ 39. 2006. pp. 22-49.

145 Sobre a influência do direito interno e internacional na democrática governância ver: CICHOWSKI, Rachel A. Courts, Democracy and Governance. Comparative Political Studies. $\mathrm{n}^{\circ}$ 39. 2006. pp. 10-11. ALTER, Karen J. Establishing the supremacy of European Law. The making of an international rule of law in Europe. Oxford: Oxford University Press. 2001. SLAUGHTER, Anne-Marie. A global community of courts. Havard International Law Journal, $\mathrm{n}^{\circ}$ 44. 2003. p. 191-219. SWEET, Alec Stone; BRUNELL, Tom. Constructing a Supranational Constitution: Dispute resolution and governance in the European Community. American Political Science Review. no 92. 1998. pp. 63-81. 
Europeia, ${ }^{146}$ bem como entre os órgãos que interpretam e julgam os litígios são um bom exemplo de questões de potenciais conflitos. ${ }^{147} \mathrm{~A}$ adoção das convenções europeias no sistema inglês possibilitou abertura para a reinterpretação dos precedentes sobre o enfoque da União Europeia. ${ }^{148}$ No mesmo sentido, a adoção da reforma constitucional no Reino Unido (Constitutional Reform Act 2005), ${ }^{149}$ com a criação da Suprema Corte, significa uma importante mudança nesse sistema judicial. No plano do direito comparado, a alteração representa uma aproximação dos modelos de sistema judicial da Europa continental, aponta para uma separação mais nítida entre os poderes, principalmente entre o sistema legislativo e judicial, e reforça, assim, a independência do Poder Judiciário a fim de responder as exigências europeias, notadamente quanto aos direitos humanos. ${ }^{150}$

No cenário brasileiro, as questões decididas pelo STF passam a ser mais integradas dentro de um sistema de resolução supranacional de conflitos. Existe uma

146 As alterações promovidas parecem dar mostras de que a globalização favorece o alargamento das representações da common law (pragmatismo na abordagem, prestígio alargado do juiz, autoridade do precedente, importância do caráter público conferido aos argumentos, confronto das partes).

147 No Reino Unido, em face da supremacia do Parlamento, o sistema constitucional apresenta marcantes diferenças relativamente a países europeus que possuem Tribunais Constitucionais. Contudo, cada vez mais, os tribunais britânicos se servem do termo constitucional para descrever certas disposições legislativas de caráter fundamental. Como o Reino Unido não possui uma Constituição escrita e permite a modificação legislativa pela via ordinária, não existe distinção entre leis constitucionais e leis ordinárias. Mas isto não implica em dizer que todas as disposições legislativas ocupam a mesma categoria no plano do direito constitucional substancial. Sobre as decisões em que prevaleceram as normas de conteúdo substancial constitucional no Reino Unido. Ver: BELL, John. Droit Constitutionnel ètranger. L'actualité constitutionnelle dans les pays de commow law et de droit mixte (janvier-juin 2002), Canada, Royaume-Uni. Revue française de droit constututinnelle. $\mathrm{n}^{\circ}$ 53. 2003. pp. 197-203.

148 A Convenção Europeia dos Direitos do Homem, por força do Human Rights Act de 1998, tornou-se aplicável ao Reino Unido.

149 Sobre reforma constitucional e os motivos para a criação da Suprema Corte Constitucional no Reino Unido ver: FAIRBAIRN, Catherine; BROADBRIDGE, Sally. Constitutional Reform Bill [HL]: a Supreme Court for the United Kingdom and judicial appointments. House of Commons Library. Research paper 05/06. 2005. Disponível em: http://www.parliament.uk/commons/lib/research/rp2005/rp05-006.pdf. HOUGUE, C. Beausse. Un aspect des réformes constitutionnelles au Royaume-Uni: La disparition du Lord Chancelier. D'une Constitution non écrite vers une constitution écrite? Revue française de droit constututinnelle. $\mathrm{n}^{\circ}$ 62. 2005. pp. 291-309.

150 A decisão do Tribunal Europeu de Direitos Humanos, McGonnel c/ Royaume-Uni, req. 28.488/95, 8.02.2000, poderia deixar de pressagiar a possibilidade de condenação em razão da posição particular da Law of Lords, que tinha as funções legislativa e judiciária. HOUGUE, C. Beausse. Op. cit., p. 293. DUFFY, Aurélie. Droit Constitutionnel étranger. L'actualité constitutionnelle dans les pays de commow law et de droit mixte. Royaume-Uni. Revue française de droit constututinnelle. $\mathrm{n}^{\circ}$ 66. 2006. pp. 399-401. 
intensificação de intercâmbios entre os sistemas de justiça que deverão conviver harmonicamente. ${ }^{151}$ Os Tribunais supranacionais que têm jurisdição no Brasil são o Tribunal Interamericano de Direitos Humanos, com competência para julgar, no âmbito do continente americano, os casos de lesão aos direitos humanos que lhe forem submetidos, além do Tribunal Penal Internacional. ${ }^{152} \mathrm{O}$ Protocolo de Olivos, por sua vez, estabelece um novo marco jurídico no caminho da justiça supranacional para o MERCOSUL, com a formação do Tribunal Arbitral Permanente de Revisão do MERCOSUL. O processo de integração certamente levará à criação de um Tribunal comunitário no âmbito do MERCOSUL. ${ }^{153}$

$\mathrm{Na}$ divisão de atribuições, os tribunais nacionais com funções constitucionais devem controlar a ação de outros agentes, no quadro de suas competências e na responsabilidade política e jurídica interna, ao passo que as cortes supranacio-

151 Sobre o aumento da referência às decisões estrangeiras pelos tribunais ver: ALLARD, Julie; GARAPON, Antoine. Les Juges dans la Mondilisation. La nouville revólution du droit. Paris: Le Seuil. 2005

152 Sobre o Tribunal Penal Internacional e mecanismos não judiciais de resolução de conflitos a nível supranacioanal ver: BORAINE, Alex. Transitional Justice. In: Making States Work. State failure and the crisis of governance. CHESTERMAN, Simon; IGNATIEFF, Michael; THAKUR, Ramesh (orgs.). United Nations University. 2005. pp. 318-338.

153 Há que ser feita referência, ainda, à União de Nações Sul-Americanas (UNASUL), formada pelos doze países da América do Sul. O tratado constitutivo da organização foi aprovado durante Reunião Extraordinária de Chefes de Estado e de Governo, realizada em Brasília, em 23 de maio de 2008. Dez países já depositaram seus instrumentos de ratificação (Argentina, Brasil, Bolívia, Chile, Equador, Guiana, Peru, Suriname, Uruguai e Venezuela), completando o número mínimo de ratificações necessárias para a entrada em vigor do Tratado no dia 11 de março de 2011. Conforme o artigo $2^{\circ}$ do Tratado Constitutivo, "A União de Nações Sul-americanas tem como objetivo construir, de maneira participativa e consensuada, um espaço de integração e união no âmbito cultural, social, econômico e político entre seus povos, priorizando o diálogo político, as políticas sociais, a educação, a energia, a infraestrutura, o financiamento e o meio ambiente, entre outros, com vistas a eliminar a desigualdade socioeconômica, alcançar a inclusão social e a participação cidadã, fortalecer a democracia e reduzir as assimetrias no marco do fortalecimento da soberania e independência dos Estados." São órgãos da União: 1. O Conselho de Chefas e Chefes de Estado e de Governo; 2. O Conselho de Ministras e Ministros das Relações Exteriores; 3. O Conselho de Delegadas e Delegados; 4. A Secretaria Geral. Não há previsão de um órgão com natureza de tribunal. No que respeita à solução de controvérsias, o Tratado dispõe, no artigo 21: As controvérsias que puderem surgir entre Estados Partes a respeito da interpretação ou aplicação das disposições do presente Tratado Constitutivo serão resolvidas mediante negociações diretas. Em caso de não se alcançar uma solução mediante a negociação direta, os referidos Estados Membros submeterão a controvérsia à consideração do Conselho de Delegadas e Delegados, o qual, dentro de 60 dias de seu recebimento, formulará as recomendações pertinentes para sua solução. No caso de não se alcançar uma solução, essa instância elevará a controvérsia ao Conselho de Ministras e Ministros das Relações Exteriores, para consideração em sua próxima reunião. 
nais apresentam uma margem de manobra mais larga e podem traçar diretrizes mais homogêneas para a afirmação de direitos ofendidos, pois estão mais distantes deste cenário. ${ }^{154}$ Os tribunais supranacionais também são menos sensíveis às pressões dos grupos de influência enraizadas ao nível local.

Atualmente, contudo, o acesso aos tribunais supranacionais é dificultado por inúmeras barreiras: falta de conhecimento e informação; custos financeiros; participação restrita. É necessário ampliar o acesso às instâncias supranacionais para aumentar o número de pessoas e grupos de interesses na participação do desenvolvimento, monitoramento e execução de direitos, quer em nível doméstico quer em nível internacional. ${ }^{155}$

Por outro lado, novas esferas de resolução de conflitos (arbitragem e mediação) ganham destaque no cenário internacional. Há uma ampliação do acesso aos esquemas de resolução de conflitos para atingir a coesão social. Apesar das aparentes diferenças entre a ideologia da justiça formal e da justiça alternativa, as duas formas de discurso ideológico coexistem, sustentando-se reciprocamente e definindo a identidade de oposição do outro. ${ }^{156}$

A arbitragem comercial internacional é uma via muito utilizada e dotada de algumas vantagens em relação aos sistemas judiciais, como a extraterritorialidade, a transcendência das diferenças culturais e a desvinculação com a soberania. A imparcialidade da arbitragem advém do órgão colegiado que profere o julgamento, composto por integrantes de diferentes interesses. Contudo, o sistema da arbitragem não apresenta somente vantagens e a relação das forças é uma questão primordial. Relativamente aos tribunais nacionais, os árbitros mostram-se mais favoráveis às grandes empresas e corporações e menos sensíveis a outras questões fundamentais, como o meio ambiente.

154 CALLEJÓN, Francisco Balaguer. Niveaux el techniques internes et internationaux des droits en Europe. Une perspective constitutionnelle. Revue française de droit constitutinnelle. $\mathrm{n}^{\circ}$ 60. 2004. p. 690.

155 CICHOWSKI, Rachel; SWEET, Alec Stone. Participation, representative democracy and the courts. In: Democracy transformed? Expanding political opportunities in advanced industrial democracies. B. Cain; R. Dalton; S. Scarrow (eds). Oxford: Oxford University Press. 2003. pp. 192-220.

156 Sobre meios alternativos de resolução de conflitos ver: SARGENT, Neil C. Is there any justice in alternative justice? In: Law, regulation and governance. NEIL, Michael Mac; SARGENT, Neil C.; Swan, Peter (eds.). Ontário: Oxford university press. 2002. p. 204-222. ZUCKERMAN, Adrian A. S. Civil Justice in Crisis - Comparative Perspectives of Civil Procedure. Oxford: Oxford University Press. 1999. No Canadá ver: PICARD, Cheryl A.; SAUNDERS, R. P. The regulation of mediation. In: Law, regulation and governance. NEIL, Michael Mac; SARGENT, Neil C.; Swan, Peter (eds.). Ontário : Oxford university press. 2002. p. 222-241. Em Portugal ver: PEDROSO, João. Percurso(s) da(s) reforma(s) da administração da justiça - uma nova relação entre o judicial e o não judicial. Oficina do Centro de Estudos Sociais. $n^{\circ}$ 171. 2002. 
O STF e os demais tribunais precisam estar atentos às transformações e remodelações. A incorporação de novos mecanismos de good governance deve proporcionar, na medida do possível, que as decisões sejam tomadas por meio de satisfação mútua e cooperação, sendo negociadas e deliberadas entre os envolvidos. A mediação, nessa senda, é um importante instrumento de prevenção e resolução de conflitos, pois evita disputas judicializadas, promove soluções mais próximas da vontade das partes, não movimenta os complexos mecanismos judiciais, e tem custos mais baixos. ${ }^{157}$

A transformação do sistema de resolução de conflitos é percebida na própria estrutura do poder judiciário. No caso brasileiro é possível citar a inserção de técnicas de conciliação e mediação, especialmente nos juizados especiais federais, estaduais e trabalhistas. Ainda, independentemente das hipóteses legais, há uma clara política nos tribunais, coordenada pelo Conselho Nacional de Justiça, para implementação de técnicas de mediação e conciliação nos processos tradicionais.

\section{OS PRINCÍPIOS DA GOOD GOVERNANCE}

Os aprimoramentos da função judicial passam pela adoção de boas práticas correlacionadas aos princípios que informam a boa governância, ou seja, transparência, responsabilidade, eficácia, eficiência, participação e coerência.

\subsection{TransParênCia}

Entre as principais aspirações da sociedade civil organizada estão o acesso à informação e a livre expressão. ${ }^{158} \mathrm{O}$ interesse consiste em conhecer, acompanhar e refletir sobre os atos privados e da administração pública, inclusive do judiciário. Os meios de comunicação têm um papel fundamental no acesso à informação, que é facilitada pelas novas tecnologias. A função da imprensa de informar, quando exercida com seriedade, profissionalismo e de maneira imparcial, constitui fundamental mecanismo de controle social das instituições, além de contribuir para aproximação do judiciário com a sociedade.

A publicidade e a fundamentação dos atos são maneiras eficientes de evitar a arbitraridade. Por isso, as decisões judiciais devem ser fundamentadas e publicadas

157 Sobre a resolução alternativa de conflitos ver: RICHARDSON, Genevra; GENN, Hazel. Tribunals in transition: resolution or adjudication. Public Law. Spring, 2007. p. 116-141. ADLER, Michael. Tribunal Reform: proportionate dispute resolution and the pursuit of administrative justice. The modern Law Review Limited. 2006. pp. 958-985.

158 Convenção Americana de Direitos Humanos dispõe no artigo 13, item 3 que: "Não se pode restringir o direito de expressão por vias e meios indiretos, tais como o abuso de controles oficiais ou particulares de papel de imprensa, de frequências radioelétricas ou de equipamentos e aparelhos usados na difusão de informação, nem por quaisquer outros meios destinados a obstar a comunicação e a circulação de ideias e opiniões." 
no Diário Oficial. A partir da Emenda Constituticonal no 45/04, as decisões administrativas dos tribunais também são motivadas e deliberadas em sessão pública. Contudo, a mera publicidade e fundamentação dos atos já não são suficientes.

A transparência, nessa esteira, é um plus. Importa na demonstração ampla de todos os atos relacionados ao bom desempenho da gestão dos tribunais, não se restringindo a fundamentação e publicidade do ato. A transparência implica na organização completa de dados e informações sobre o que acontece nos tribunais. A comunicação contínua e direta dos trabalhos desenvolvidos pelo judiciário facilita o acesso do maior número de pessoas e promove a verificação e a discussão sobre as atividades judiciais. A transparência poderá clarificar questões importantes sobre o modo e a forma como trabalham os integrantes do judiciário, o processo de deliberação e as interações com a sociedade, além de outras questões muitas vezes obscuras como a assiduidade, produtividade, eficiência, desempenho, capacitação e experiências multidisciplinares.

A acessibilidade das informações contribui, assim, para o aperfeiçoamento do sistema judicial, além de facilitar o trabalho dos profissionais da área jurídica. Desse modo, o STF e os tribunais devem divulgar amplamente à sociedade civil de seus atos, salvo aqueles que sejam imprescindíveis à segurança da sociedade, do Estado e à intimidade dos particulares. Os novos meios tecnológicos auxiliam na prossecução da transparência. Tem-se, por exemplo, a internet como importante mecanismo de transparência pela facilidade e rapidez do processamento dos dados, além do o rádio e da televisão, valendo ressaltar que o Brasil é único país que transmite pela rádio e televisão, ao vivo, todas as sessões do STF.

A transparência também pode combater questões pontuais do judiciário, principalmente quanto aos chamados processos "engavetados", ou seja, processos que por diversos motivos têm duração mais longa do que a média normal. O máximo de segredo acaba por facilitar a corrupção. Ao contrário, quanto maior a transparência, tendencialmente menor é a probabilidade de corrupção, é dizer, a transparência é o outro lado do problema da corrupção. ${ }^{159}$

A transparência também deve ser levada a todos os atos processuais. $\mathrm{O}$ judiciário deve modernizar-se e adaptar-se aos novos recursos tecnológicos que facilitam o desenvolvimento dos processos judiciais. A gravação de audiências, por exemplo, mediante recursos audiovisuais, retrata com maior facilidade os fatos que aconteceram nessa audiência. Assim, a transparência pode levar a uma maior clareza nos julgamentos.

Além disso, com a implantação efetiva da transparência talvez seja possível esclarecer ou encontrar pistas sobre o mito da morosidade e da lentidão que envolvem o poder judiciário. No plano supranacional, a transparência das informações

159 CANOTILHO, J. J. Gomes. O tempo curvo de uma carta (fundamental) ou direito constitucional interiorizado. Porto: Conselho Distrital do Porto da Ordem dos Advogados. 2008. pp. 19-20. 
pode levar ao conhecimento de diferentes países práticas adotadas em lugares com peculiaridades não difundidas em outros países. ${ }^{160}$

Por fim, a respeito da transparência na condução dos assuntos públicos, deve-se dispensar algumas palavras à designada "Lei de Acesso à Informação" (Lei 12.527/2011). Regula essa Lei o exercício do direito de acesso à informação previsto no artigo $5^{\circ}$, inciso XXXIII, no artigo 37 , inciso II, $\S 3^{\circ}$ e no artigo 216 , $\S 2^{\circ}$, todos da Constituição da República. Disciplina, portanto, conforme dispõe no artigo $1^{\circ}$, os procedimentos a serem observados pela União, Estados, Distrito Federal e Municípios, com o fim de garantir o acesso a informações previsto nos precitados dispositivos.

O Poder Judiciário, nos termos do parágrafo único, I, do artigo $1^{\circ}$, subordina-se também ao regime instituído por essa Lei. Os procedimentos previstos na Lei, destinados, como já dito, a concretizar o direito fundamental de acesso à informação, devem observar, para além dos princípios regentes da Administração Pública em geral, diretrizes específicas previstas no artigo $3^{\circ}$ : I - observância da publicidade como preceito geral e do sigilo como exceção; II - divulgação de informações de interesse público, independentemente de solicitações; III - utilização de meios de comunicação viabilizados pela tecnologia da informação; IV - fomento ao desenvolvimento da cultura de transparência na administração pública; V - desenvolvimento do controle social da administração pública.

A Lei ainda estabelece as seguintes obrigações aos órgãos a ela sujeitos (artigo $6^{\circ}$ ): I - gestão transparente da informação, propiciando amplo acesso a ela e sua divulgação; II - proteção da informação, garantindo-se sua disponibilidade, autenticidade e integridade; e III - proteção da informação sigilosa e da informação pessoal, observada a sua disponibilidade, autenticidade, integridade e eventual restrição de acesso. Além disso, prescreve no artigo $8^{\circ}$ : É dever dos órgãos e entidades públicas promover, independentemente de requerimentos, a divulgação em local de fácil acesso, no âmbito de suas competências, de informações de interesse coletivo ou geral por eles produzidas ou custodiadas.

O artigo 21, por seu turno, assegura importante garantia à proteção de direitos:

Art. 21. Não poderá ser negado acesso à informação necessária à tutela judicial ou administrativa de direitos fundamentais.

Parágrafo único. As informações ou documentos que versem sobre condutas que impliquem violação dos direitos humanos praticada por agentes públicos ou a mando de autoridades públicas não poderão ser objeto de restrição de acesso.

Trata-se, indubitavelmente, de instrumento normativo valioso à implementação do princípio da transparência no âmbito do Poder Judiciário, de modo geral, e

160 KISKIS, Mindaugas; PETRAUSKAS, Remantas. ICT. Adoption in the Judiciary: Classifying of Judicial Information. International Review of Law Computers \& Technology. 2004. pp. 18-45. 
no Supremo Tribunal Federal, de modo específico.

\subsection{RESPONSABILIDADE}

A responsabilidade dos integrantes do poder judiciário é um importante tema no debate atual. ${ }^{161}$ A principal questão é saber para quem presta contas da sua atividade um membro do poder judiciário, e como e quando os tribunais podem fornecer mais responsabilidade institucional ? $^{162}$ Os membros de qualquer empresa ou entidade são avaliados por seus atos, que repercutem em benefícios ou perdas dentro do campo de trabalho. A classe política é avaliada nas eleições. Geralmente, o poder judiciário não apresenta mecanismos efetivos de avaliação e de responsabilização dos seus membros. O levantamento de dados estatísticos não é suficiente. As corregedorias desempenham um importante papel no que respeita ao controle disciplinar e administrativo. Todavia, trata-se de um controle mais repressivo do que preventivo, ou seja, os juízes e ministros não são submetidos a processos contínuos de avaliação interna.

A questão aqui tratada ultrapassa a responsabilidade civil, penal e administrativa, inerente a qualquer pessoa integrante de um cargo público. A autonomia administrativa e financeira dos tribunais (artigo 99 da Constituição) não os exime de prestarem as suas contas perante os Tribunais de Contas. A criação do Conselho Nacional de Justiça ${ }^{163}$ e do Conselho Nacional do Ministério Público, pela Emenda Constitucional $n^{\circ} 45 / 04$, representou um importante avanço para o controle das atividades do Poder Judiciário. Contudo, esses mecanismos constitucionais não englobam nenhuma outra forma expressa de avaliação e responsabilização dos membros do judiciário. Atualmente, a avaliação restringe-se a uma responsabilidade pessoal, ou seja, relaciona-se com a consciência de cada juiz ou ministro no e pelo exercício de sua atividade. O juiz institucionalmente responsável cumpre as suas obrigações específicas de caráter individual e assume um compromisso ativo no bom funcionamento de todo o sistema judicial.

A nova governância implica na implementação efetiva do princípio da res-

161 Sobre questões relacionadas a responsabilidade do juízes e independência, atuação em políticas públicas e modelos de resposabilidade ver: GARAPON, Antoine. Les juges. Un pouvoir irresponsable? Paris: Nicolas Philippe. 2003.

162 Sobre como e quando os tribunais podem fornecer mais responsabilidade institucional: GRABER, Mark. A. The non-majority difficulty. Legislative diference to the judiciary. Studies in American. Political Development, 7. 1993. pp. 35-72. LOVELL, George. Legislative deferrals: Statutory ambiguity, judicial power, and American democracy. New York: Cambridge University Press. 2003.

163 Sobre o Conselho Nacional de Justiça ver: COSTA, Flávio Dino de Castro. O Conselho Nacional de Justiça: competências e aspectos processuais. In: Vladimir Passos de Freitas e Dario Almeida Passos de Freitas (orgs.). Direito e administração da justiça. Curitiba: Editora Juruá. 2006. pp. 77-95. 
ponsabilização e pode ajudar a responder esta questão. É imprescindível criar mecanismos de avaliação permanente e periódica para diagnosticar as mazelas e exercer melhor o controle. A avaliação também deve abranger a administração da justiça e verificar a eficiência da prestação dos serviços judiciais. A participação da sociedade civil é relevante para o sucesso da avaliação e da responsabilização, pois impende haja sintonia profunda entre as medidas adotadas pelo judiciário e as aspirações dos cidadãos.

O controle e a responsabilização ajudam ainda a reduzir a corrupção. A corrupção é um fenómeno extremamente complexo. Consiste em um esquema coletivo, e não isolado. Existe na medida em que é vantajosa para os envolvidos. No poder judiciário, as principais ocorrências de corrupção ${ }^{164}$ estão relacionados a licitações, concursos públicos, nepotismo, indústria de indenizações e liminares e tráfico de influência. Sua incidência maior advém da ausência de mecanismos de controle dos agentes por meio da responsabilização. Portanto, a responsabilidade deve ser constitucionalizada como uma garantia das condições norteadoras do sistema político-jurídico e social, sob as quais podem coexistir as diversas perspectivas de valor, conhecimento e ação. ${ }^{165}$

\subsection{Participação}

No âmbito do STF é cada vez mais difundida a participação dos integrantes da sociedade nos processos judiciais de repercussão social ou economicamente ampliada. Diversos instrumentos legislativos ${ }^{166}$ passaram a prever a possibilidade de intervenção de terceiros no processo com a finalidade de esclarecer, subsidiar e informar sobre as questões discutidas no processo judicial. O sistema judicial brasileiro adotou o instituto do animus curiae, de origem norte-americana e que apresenta um forte conteúdo de participação política e democrática na decisão sobre assuntos relevantes para a coletividade.

A participação da sociedade civil nos assuntos judicializados é extremamente relevante, porquanto é ela a destinatária final da prestação jurisdicional. O processo de decisões administrativas no âmbito dos tribunais deve contar também

164 A maior expressão visível de investigação sobre a corrupção no poder judiciário no Brasil ocorreu com a Comissão Parlamentar de Inquérito (CPI) do Judiciário do Congresso Nacional no ano de 1999. O principal fato investigado referia-se ao superfautramento das obras de construção do Tribunal Regional do Trabalho de São Paulo.

165 CANOTILHO, J. J. Gomes. “Brancosos”, .., cit., p. 129.

$166 \mathrm{O}$ artigo $7^{\circ}, \S 2^{\circ}$, da Lei $9.868 / 99$ possibilita a manifestação de terceiros nos processos de controle de constitucionalidade concentrado, considerando-se a relevância da matéria e a representatividade dos postulantes; o artigo $14, \S 7^{\circ}$ da Lei $10.259 / 01$, no incidente de uniformização de interpretação de lei federal; a Lei 11.418/06 inseriu o artigo 543-A, § $6^{\circ}$, no Código de Processo Civil, que dispõe sobre a intervenção de terceiro na comprovação da repercussão geral de questão constitucional para recebimento de recurso extraordinário. 
com a participação de magistrados de primeiro grau e dos cidadãos. A ausência de participação nos processos decisórios dos tribunais pode ser exemplificada com um caso relativamente recente. Em vista dos conflitos gerados no calor da crise aeroportuária, instalaram-se juizados especiais em cinco aeroportos brasileiros. Após a instalação, muitas críticas foram dirigidas à medida, pois, mesmo que importante, revelou ela a inexistência de participação dos magistrados e cidadãos na tomada da decisão.

\subsection{COERÊNCIA}

A governância pode apresentar novas opções e caminhos para os sistemas judiciais. Os sistemas são cada vez mais complexos, diversificados e híbridos. As esferas de poder social organizatório transcendem ao poder judiciário estatal e necessitam ser coordenadas e integradas por meio de ações coesas. A condução do processo deve iniciar com os atores principais (STF e tribunais) e se irradiar para a sociedade e os cidadãos. A coerência entre todas as ações promoverá a intensidade ideal de ligação entre os atores (estatais e da sociedade civil) que participam da rede de sistemas de resolução de conflitos.

O grande desafio do STF e de todo o sistema judicial brasileiro, em termos de coerência, é realizar a unificação dos sistemas judiciais (justiça eleitoral, militar, do trabalho, federal e estadual) e promover harmonicamente a inserção das demais formas de resolução de conflitos. A divisão de trabalho entre os juízes é importante para a otimização dos serviços, mas atualmente carece-se de integração administrativa e jurisdicional. As boas práticas de um setor precisam ser levadas aos demais em prol de objetivos comuns em torno da excelência da prestação jurisdicional. A informatização dos sistemas judiciais é um tema em destaque. Cada tribunal, ao seu ritmo, tem elaborado programas de tramitação virtual de processos que são utilizados em primeira e segunda instâncias. Contudo, esses processos judiciais e eletrônicos podem chegar aos tribunais superiores. Então, deve-se perguntar, o que é mais racional, lógico, prático e econômico: O STF possuir os diversos programas de informática de cada tribunal para processar os recursos, ou desenvolver-se um programa que possa ser utilizado por todas as instâncias e esferas do poder judiciário? A resposta parece óbvia. O Conselho Nacional de Justiça tem assumido a responsabilidade de organizar certas questões importantes da área administrativa. O Conselho da Justiça Federal, por sua vez, é responsável somente pela administração da justiça federal. Dessarte, faz-se necessária e urgente a criação de uma estrutura administrativa que possa coordenar e integrar, de forma coerente, toda a administração da justiça brasileira, além de interagir e promover os meios alternativos de resolução de conflitos. 


\subsection{EFICÁCIA E EFICIÊNCIA}

O princípio da eficácia representa a força governativa que emprega meios adequados para a produção do efeito desejado, ou seja, os meios pelos quais se implementa a governância devem ser adequados aos fins que se pretende alcançar. Aqui reside a necessidade de aprimoramento do STF e do poder judiciário.

É comum afirmar-se, atualmente, que os processos de modernização do Estado e de desenvolvimento econômico-social passam pelo melhoramento do judiciário, sobretudo no que respeita à sua eficácia e à eficiência. ${ }^{167}$ Como uma variável determinante para a governância, o mercado requer regras de máxima simplicidade e de racionalidade elevada em função da prossecução de resultados.

A súmula vinculante e a repercussão geral sobre questão constitucional são soluções apresentadas pela reforma constitucional do judiciário com alguns objetivos específicos: controlar o excesso de demandas no STF (e também em todas as demais instâncias do judiciário); evitar decisões contraditórias; proporcionar segurança jurídica; evitar maiores prejuízos às partes. Por outro lado, existe um incremento expressivo da utilização do instrumento da reclamação, nos casos de desrespeito das decisões do STF pelas instâncias inferiores, de modo que esse instrumento assume cada vez mais o papel de ação constitucional voltada à proteção da ordem constitucional. ${ }^{168}$

\subsubsection{Repercussão geral}

A Emenda Constitucional no $45 / 04$ estabeleceu novas regras de admissibi-

167 Sobre o sistema judicial e o custo de fazer negócios ver: ALESINA, Alberto; GIAVAZZI, Francesco. O futuro da Europa, reforma ou declínio. Lisboa: Edições 70. 2007. pp. 141-150.

168 "Ressalte-se, ainda, que a EC n. 45/2004 consagrou a súmula vinculante, no âmbito da competência do Supremo Tribunal, e previu que a sua observância seria assegurada pela reclamação. (...) Nessa perspectiva, parece bastante lógica a possibilidade de que, em sede de reclamação, o Tribunal analise a constitucionalidade de leis cujo teor é idêntico, ou mesmo semelhante, a outras leis que já foram objeto do controle concentrado de constitucionalidade perante o Supremo Tribunal Federal. Como explicado, não se está a falar, nessa hipótese, de aplicação da teoria da "transcendência dos motivos determinantes" da decisão tomada no controle abstrato de constitucionalidade. Trata-se, isso sim, de um poder ínsito à própria competência do Tribunal de fiscalizar incidentalmente a constitucionalidade das leis e dos atos normativos. E esse poder é realçado quando a Corte se depara com leis de teor idêntico àquelas já submetidas ao seu crivo no âmbito do controle abstrato de constitucionalidade. Assim, em relação à lei de teor idêntico àquela que já foi objeto do controle de constitucionalidade no STF, poder-se-á, por meio da reclamação, impugnar a sua aplicação ou rejeição por parte da Administração ou do Judiciário, requerendo-se a declaração incidental de sua inconstitucionalidade, ou de sua constitucionalidade, conforme o caso". Reclamação n ${ }^{\circ} 4.987$. Rel. Min. Gilmar Mendes. 07/03/2007. 
lidade do recurso extraordinário pelo STF. ${ }^{169} \mathrm{~A}$ apreciação do recurso depende, desde então, da demonstração da repercussão geral das questões constitucionais A Lei ${ }^{0}$ 11.418/2006, que acrescentou ao Código de Processo Civil os artigos 543-A e 543$\mathrm{B}$, especificou os requisitos da repercussão geral. O instrumento é uma espécie de "filtro recursal" 170 amplamente adotado por diversas Cortes Supremas, ${ }^{171}$ tais como a Suprema Corte dos EUA ('writ of certiorari' $)^{172}$ e a Suprema Corte da Argentina ('requisito de transcendência'). ${ }^{173}$

169 Art. $102 \S 3^{\circ}$. "No recurso extraordinário o recorrente deverá demonstrar a repercussão geral das questões constitucionais discutidas no caso, nos termos da lei, a fim de que o Tribunal examine a admissão do recurso, somente podendo recusá-lo pela manifestação de dois terços de seus membros."

170 Carlos Velloso, em 1998, quando ainda integrava o quadro do STF, propôs a adoção de um requisito de relevância da questão de direito federal discutida, como condição de admissibilidade de recurso extraordinário, inspirada na experiência americana. (VELLOSO, Carlos Mário da Silva. Do poder judiciário: como torná-lo mais ágil e dinâmico. Efeito vinculante e outros temas. Revista de Informação Legislativa. $\mathrm{n}^{\circ}$ 138. Brasília. 1998. p. 75-87, p. 81).

171 Sobre a doutrina alemã que defende um procedimento de livre admissão de recurso para o Tribunal Constitucional, inspirado na prática da Suprema Corte dos Estados Unidos: WAHL, Rainer; WIELAND, Joachim. La jurisdiccion constitucional como bien escaso el acesso al bundesverfassungsgerichtI. Revista Española de Derecho Constitucional. ${ }^{\circ} 5$. 1997.

172 De acordo com a sistemática adotada pela Suprema Corte dos Estados Unidos qualquer tipo de questão que chegue à Corte passa inicialmente por um processo preliminar de triagem e somente se justifica uma nova revisão naqueles casos que o tribunal considere suficientemente importantes ou significativos. De acordo com a Lei Judiciária de 1925, o Congresso norte-americano ampliou a competência certiorari daquela instituição, dando-lhe ao mesmo tempo maior poder de controle sobre seu volume de trabalho. Em 1988, o Congresso reduziu ainda mais a jurisdição obrigatória da Suprema Corte. Então, a instituição tem total poder discricionário sobre sua competência. Atualmente, utilizando o writ of certiorari, a Suprema Corte considera somente os processos "de importância geral e grande seriedade" e que envolvam princípios de amplo interesse público ou governamental. Os juízes seguem o que é conhecido como a "Regra dos Quatro", isto é, será concedido o cert se estiverem a favor dele quatro juízes. Não é uma regra escrita, mas decorre de uma tradição antiga. Se uma "minoria considerável" achar que o caso deva ser apreciado e receber um parecer (não necessariamente decidido de uma forma determinada), a Suprema Corte deve considerar os méritos e dar uma decisão sobre o processo.

173 A proposta aproxima-se da interpretação do Tribunal Constitucional alemão quanto ao "direito constitucional específico", introduzida pela sentença BverfGE 18, 85, 92, chamada fórmula de Heck (STARCK, Christian. Jurisdiccion Constitucional y tribunales ordinarios. Revista Española de Derecho Constitucional. $\mathrm{n}^{\circ}$ 53. 1998. p. 17-18). O direito constitucional que sirva de critério para a atividade de admissão do recurso é de categoria superior ao respectivo direito ordinário, ou seja, somente quando a violação for direta à Constituição deve ser admitido o recurso extraordinário. Em sentido contrário, Wahl e Wieland, entendem que a expressão direito constitucional específico não remete a um parâmetro, mas a um problema. 
O instituto realça o debate sobre a adoção do princípio da legalidade ou da oportunidade quanto às questões a serem aceitas em sede recursal pelo STF. No sistema até então vigente prevalecia a legalidade estrita, de sorte que todas as questões de afronta direta à Constituição deveriam ser apreciadas. Pela atual sistemática, insere-se no sistema constitucional brasileiro a discricionariedade quanto à admissão do recurso extraordinário. A discricionariedade está atrelada às questões relevantes do ponto de vista econômico, político, social ou jurídico.

O STF não pode e nem deve querer resolver todos os casos. Deve, antes, ocupar-se prioritariamente das questões de cunho tipicamente constitucional, ou seja, das questões de alta repercussão política, social e econômica. As demandas de menor repercussão devem ser solucionadas pelos demais tribunais judiciais. Neste contexto, revela-se importante estabelecer mecanismos para a separação entre questões de alta e de baixa repercussão constitucional. Por outro lado, é relevante saber se a discricionariedade é total ou condicionada a parâmetros legais. Da forma como foi estabelecido o instituto, a discricionariedade parece ser total, ou seja, o STF poderá interpretar livremente se a questão debatida no processo apresenta repercussão geral.

Contudo, não há vício constitucional na medida, pois somente as questões mais relevantes devem ser submetidas à análise do STF. Institutos de controle sobre as demandas a serem julgadas pelo tribunal com função constitucional já existem em outros sistemas jurídicos. Cabe à Suprema Corte delinear e complementar o conceito aberto ${ }^{174}$ de "questões de alta relevância política, econômica, social e jurídica". Caso não corresponda ao sentido constitucionalmente atribuído ao conceito, a construção do STF poderá sofrer alteração pela via legislativa. Insta salientar, igualmente, que a sociedade civil poderá participar do processo de acolhimento da questão com repercussão geral, por meio da manifestação junto ao processo judicial, apresentando razões para a aceitação da medida pelo STF.

O STF fixou os seguintes parâmetros interpretativos sobre a repercussão geral: 1) é de exigir-se a demonstração da repercussão geral das questões constitucionais discutidas em qualquer recurso extraordinário, incluído o criminal; 2) a verificação da existência de demonstração formal e fundamentada da repercussão

A fórmula encobre um suposto decisionismo, pois o próprio Tribunal decide o que constitui uma violação do direito especificamente constitucional: WAHL, Rainer; WIELAND, Joachim. Op. cit., p. 18.

174 "Mesmo que o legislador constituinte recorra a uma regulamentação a mais completa possível do direito material, não poderá ter de antemão preparadas respostas explícitas para todos os problemas. A utilização de cláusulas gerais e de conceitos dotados de um alto grau de indeterminação e abstração tornam premente a necessidade da sua complementação" (QUEIROZ, Cristina. Interpretação constitucional e poder judicial: sobre a epistemologia da construção constitucional. Coimbra: Coimbra Editora. 2000. p. 109). A presença de princípios jurídicos e cláusulas abertas nas Constituições proporciona uma maior liberdade na interpretação judicial, em razão do considerável grau de indeterminação e abstração de seus enunciados. 
geral das questões discutidas no recurso extraordinário pode fazer-se tanto na origem quanto no STF, cabendo exclusivamente a este Tribunal, no entanto, a decisão sobre a efetiva existência da repercussão geral; 3) a exigência da demonstração formal e fundamentada no recurso extraordinário da repercussão geral das questões constitucionais discutidas só incide quando a intimação do acórdão recorrido tenha ocorrido a partir de 03 de maio de 2007, data da publicação da emenda regimental $n^{\circ} 21$, de 30 de abril de $2007 .{ }^{175}$

Há que se realizar, por fim, após alguns anos de instituto de repercussão geral, uma observação crítica a respeito do grande número de casos em que se reconheceu repercussão geral, mas relativamente aos quais não foi ainda proferido julgamento final pelo STF. Noutro falar, existe número importante de casos com repercussão geral reconhecida e parados, pendentes de julgamento. Essa circunstância, para além de configurar um mal em si própria, tem ainda um danoso efeito colateral. É que a prática jurisprudencial tende, nas instâncias inferiores, a suspender os processos em que se discutem questões nas quais o STF reconheceu repercussão geral. Assim, enquanto não ocorre julgamento, pelo STF, do leading case em que foi primeiramente reconhecida e repercussão, os demais casos idênticos continuam suspensos nas instâncias inferiores, aguardando julgamento que, não raro, tarda anos a ser proferido.

\subsubsection{Súmula vinculante}

A emenda constitucional $n^{\circ} 45 / 04$ acrescentou ainda no sistema da justiça constitucional brasileira o instituto da súmula vinculante (artigo 103-A da Constituição). Trata-se de instituto de caráter normativo e sensivelmente distinto, do ponto de vista conceitual, das antigas súmulas ou do que se entende por "jurisprudência".

É dizer, as súmulas podem ser classificadas em vinculantes e não vinculantes. ${ }^{176} \mathrm{~A}$ súmula comum ou não vinculante é uma mera síntese de decisões do tribunal sobre normas, enquanto as súmulas vinculantes possuem poder normati-

175 STF. Tribunal Pleno. Agravo de instrumento no 664.567/RS. Relator Sepúlveda Pertence. j. 18.06.2007. DJ. 26.06.2007).

176 De acordo com o Ministro Gilmar Mendes, "não se confundem as figuras das súmulas “ordinárias" (tradicionais), disciplinadas desde há mais de 40 (quarenta) anos no RISTF (atualmente, arts. $7^{\circ}$, VII, e 102-103, especialmente) e voltadas a consolidar a jurisprudência da Corte e facilitar a remissão aos seus principais entendimentos consagrados, e as 'súmulas vinculantes', introduzidas em nosso ordenamento constitucional pela EC n ${ }^{\circ} 45 / 04$ (disciplinadas no vigente art. 103-A da Lei Maior) e destinadas a vincular compulsoriamente) o entendimento jurídico e a sua execução material, na Administração Pública (direta e indireta) e nos demais órgãos do Poder Judiciário (ou seja, todos os órgãos à exceção do próprio STF), à exegese que em matéria constitucional proferir e assim decidir classificar esta Corte". (STF. Tribunal Pleno. Agravo Regimental na Reclamação n 5.082-3/DF. Relatora Ellen Gracie. j. 19.04.2007. DJ. 04.05.2007). 
vo e vinculante. Em regra, as súmulas não são vinculantes e podem ser editadas por todos os tribunais ou turmas recursais, mas somente o STF pode editar as súmulas vinculantes. Todas as súmulas editadas pelo STF até o advento da Lei ${ }^{\circ}$ 11.417/2006 são não vinculantes. Para serem vinculantes devem seguir rigorosamente o procedimento previsto para sua edição. ${ }^{177}$

A súmula vinculante representa o entendimento pacífico do STF sobre determinada matéria constitucional. A Corte, após reiteradas decisões sobre matéria constitucional, poderá editar enunciado de súmula que, a partir de sua publicação na imprensa oficial, terá efeito vinculante em relação aos demais órgãos do poder judiciário e à administração pública direta e indireta, nas esferas federal, estadual e municipal. A Lei $\mathrm{n}^{0}$ 11.417, de 19 de dezembro de 2006, disciplina a edição, a revisão e o cancelamento de enunciado de súmula vinculante pelo STF. ${ }^{178} \mathrm{O}$ enunciado da súmula terá por objeto a validade, a interpretação e a eficácia de normas determinadas, acerca das quais haja, entre órgãos judiciários ou entre esses e a administração pública, controvérsia atual que acarrete grave insegurança jurídica e relevante multiplicação de processos sobre idêntica questão, ou seja, o objetivo é garantir a

177 Nesse sentido é o posicionamento do STF, conforme trecho extraído de acórdão paradigmático: "É dizer, o art. 103-A, $\S 3^{\circ}$, da Carta Magna, tem aplicação exclusiva às súmulas vinculantes, que possuem natureza constitucional específica e completamente distinta da Súmula STF $n^{\circ} 622$, de cunho eminentemente processual e que não vincula ou subordina os demais órgãos judiciários, como o Tribunal de Justiça do Distrito Federal e Territórios" (STF. Tribunal Pleno. Agravo Regimental na Reclamação n 3.979-0/DF. Relatora Gilmar Mendes. j. 03.05.2007. DJ. 02.06.2007).

178 Sobre o processo de edição, revisão e cancelamento do enunciado de súmula vinculante: As decisões acerca de enunciado de súmula com efeito vinculante dependerão de decisão tomada por 2/3 (dois terços) dos membros do STF, em sessão plenária. O STF poderá, de ofício ou por provocação, realizar a edição, a revisão ou o cancelamento de enunciado de súmula vinculante. São legitimados a propô-la: o Presidente da República; a Mesa do Senado Federal; a Mesa da Câmara dos Deputados; o Procurador-Geral da República; o Conselho Federal da Ordem dos Advogados do Brasil; o Defensor Público-Geral da União; partido político com representação no Congresso Nacional; confederação sindical ou entidade de classe de âmbito nacional; a Mesa de Assembleia Legislativa ou da Câmara Legislativa do Distrito Federal; o Governador de Estado ou do Distrito Federal; os Tribunais Superiores, os Tribunais de Justiça de Estados ou do Distrito Federal e Territórios, os Tribunais Regionais Federais, os Tribunais Regionais do Trabalho, os Tribunais Regionais Eleitorais e os Tribunais Militares. O Município poderá propor, incidentalmente ao curso de processo em que seja parte, a edição, a revisão ou o cancelamento de enunciado de súmula vinculante, o que não autoriza a suspensão do processo. No procedimento o relator poderá admitir, por decisão irrecorrível, a manifestação de terceiros na questão. Revogada ou modificada a lei em que se fundou a edição de enunciado de súmula vinculante, o STF, de ofício ou por provocação, procederá à sua revisão ou cancelamento, conforme o caso. A proposta de edição, revisão ou cancelamento de enunciado de súmula vinculante não autoriza a suspensão dos processos em que se discuta a mesma questão. 
segurança jurídica e evitar a multiplicação de processos sobre questão idêntica. ${ }^{179}$

No caso de descumprimento de súmula vinculante por órgãos da administração pública, a Lei ${ }^{\circ} 11.417$ impõe-lhes responsabilidade, tanto na esfera cível, quanto na penal e administrativa. Não há previsão de responsabilidade aos membros do Poder Judiciário, por entender-se que, em tal caso, a norma estaria a punir o juiz pelo exercício de algo inerente à sua função, ou seja, a interpretação das leis. Para coibir o descumprimento de súmula vinculante por instituição pública o instrumento previsto é a reclamação, a ser interposta diretamente ao STF.

Convém observar que a instituição da súmula vinculante provocou atritos que demandam novas acomodações. ${ }^{180}$ Uma importante crítica à ideia da súmula vinculante refere-se à dificuldade em condensar a essência das súmulas em proposições simples, ignorando os elementos da realidade temporal e circunstancial que são inerentes a todas as decisões judiciais. ${ }^{181}$ Outro aspecto importante, que reabre o debate sobre a legitimidade e a separação de poderes, diz respeito às funções e limites do poder judiciário. Também há muita discussão sobre o engessamento do judiciário com o cerceamento da independência do juiz e a supressão do duplo grau de jurisdição.

Antes de enfrentarmos as proposições acima expostas, é necessário expor os fundamentos para a criação da súmula vinculante. ${ }^{182}$ A complexidade e a divisão do sistema judicial brasileiro, aliado à grande extensão territorial do País e à diversidade cultural e regional proporciona divergências frequentes na interpretação das normas constitucionais. A adoção da súmula vinculante decorre da necessidade de se padronizar e uniformizar a interpretação jurídico-constitucional nas instâncias judiciais e possibilitar a aplicação isonômica do direito aos jurisdicionados que se

179 Até o momento o STF editou trinta e duas súmulas vinculantes.

180 Contra a instituição da súmula vinculante, ver: ROCHA, Carmen Lúcia Antunes. Sobre a súmula vinculante. Revista de Informação Legislativa. no 133. 1997. pp. 51-64.

181 HABERLE, Peter. Zeit und Verfassung, In: Probleme der Verfassungsinterpretation, 1976, 312-313, apud MENDES e PFLUG, 2005:350. MENDES, Gilmar Ferreira; PFLUG, S. M. Passado e futuro da súmula vinculante: considerações à luz da Emenda Constitucional n. 45/04. In: Reforma do Judiciário. RENAULT, Sérgio Rabello Tamm; BOTTINI, Pierpalo (orgs.). São Paulo: Saraiva. 2005.

182 Glauco Salomão Leite desenvolve premissas sobre as quais a problemática das súmulas vinculantes no Brasil deve ser analisada: a) o Poder Legislativo não detém o monopólio da produção normativa; b) a lei não é a única e exclusiva fonte de direito; c) a função judicial não se reduz à aplicação mecânica de textos legais; d) a interpretação jurídica envolve produção normativa; e) essa produção normativa é elevada quando se trata de interpretação da Constituição; f) a jurisdição constitucional, no desempenho de suas funções, cria normas materialmente constitucionais; g) a interpretação constitucional firmada pelo Supremo Tribunal Federal pode se sobrepor às demais interpretações desenvolvidas pelos outros intérpretes, "oficiais" e "não-oficiais", da Constituição. LEITE, Glauco Salomão. Súmula vinculante e jurisdição constitucional brasileira. Rio de Janeiro: Forense. 2007. p. 49. 
encontram na mesma situação jurídica.

Oportuno lembrar, nesse sentido, que a igualdade e certeza devem ser garantidas no momento da elaboração das leis, e, sobretudo, no momento de sua aplicação. Na sistemática anterior à súmula vinculante, as decisões proferidas em sede de controle constitucionalidade difuso valiam apenas para um único caso. A decisão do Supremo Tribunal, órgão máximo da jurisdição constitucional, era desprovida de força para se impor sobre os outros juízes e tribunais, ou seja, a mesma norma poderia ser considerada constitucional por alguns e inconstitucional para outros, propiciando forte insegurança jurídica.

Para além disso, impende sublinhar o elevado número de processos submetidos a julgamento no STF. Na maioria das vezes, envolvem as mesmas questões de direito, exigindo um esforço repetitivo e burocrático, sem acrescentar ao debate novas questões jurídicas. Assim, com a adoção da súmula vinculante se pretende conter e resolver os litígios de massa que respeitem ao mesmo problema constitucional.

$\mathrm{O}$ instituto da súmula vinculante aproxima os modelos de controle de constitucionalidade, ampliando a conexão e a articulação entre os modelos difuso e concentrado. De igual modo, a escolha do STF em relação à edição da súmula vinculante deve observar a cumulação dos requisitos da grave insegurança jurídica e da multiplicação de pleitos com questões idênticas. Portanto, ocorre uma aproximação entre os modelos existentes de garantia e de defesa da Constituição.

É verdade que a força obrigatória das súmulas quanto à interpretação nas situações análogas futuras torna-as, em certo sentido, similares aos preceitos emanados do órgão legislativo, na medida em que projetam efeitos gerais e abstratos. Contudo, não há ofensa à separação dos Poderes. Primeiramente, não é novidade que o STF cria direito por força da própria aplicação e interpretação da Constituição. ${ }^{183}$ No entanto, os processos de criação do direito apresentam características próprias, e os limites impostos ao STF são maiores e mais restritivos. $\mathrm{O}$ verbete da súmula apenas sintetiza a essência do entendimento reiterado e consolidado na jurisprudência do STF sobre determinada matéria. Há correlação entre o enunciado da súmula e o substrato jurisprudencial originário. Dessa forma, a materialização das súmulas vinculantes em verbetes linguísticos não os torna produto de atividade legislativa nem ofende a separação dos poderes.

No mesmo sentido, não merece prosperar a tese de que as súmulas vinculantes implicariam em engessamento da jurisprudência, impedindo sua evolução diante dos influxos da realidade subjacente. A possibilidade de revisão e cancelamento das súmulas assegura a dinâmica da jurisprudência constitucional e permite rever suas concepções a respeito de determinado tema. Assim, é possível evitar-se a estagnação do fluxo criativo da jurisprudência, e não se obsta, pelo mesmo motivo, sua adaptação às novas emergências.

183 SWEET, Alec Stone. The Juridical Coup d'État and the Problem of Authority. German Law Journal. v. 8, $\mathrm{n}^{\mathrm{o}}$ 10. 2007. p. 916. 
Por outro lado, os representantes da sociedade pluralista têm acesso às discussões sobre a interpretação constitucional e podem oferecer propostas e soluções que considerem adequadas para a edição, revisão ou cancelamento da súmula vinculante. Abre-se um espaço democrático de debate para a sociedade civil organizada e a esfera pública, ou seja, as deliberações a respeito das súmulas vinculantes não se restringem às partes e aos membros do STF. ${ }^{184} \mathrm{O}$ esforço de todos pode produzir com mais facilidades as modificações das súmulas editadas, quando se fizer necessário procurar argumentos novos, aspectos inexplorados nos velhos argumentos, ou apontar as modificações da própria realidade social, política, cultural ou econômica.

Outrossim, não há que se falar em cerceamento da independência do juiz em razão da súmula vinculante. Ao magistrado sempre restaria a possibilidade de avaliação quanto ao conteúdo da súmula e dos precedentes originários, aquando da sua aplicação ou não a um determinado caso concreto. É que a súmula vinculante, no modelo brasileiro, difere do modelo americano da stare decisis, porquanto, entre nós, não incorpora os casos concretos que formam a base para a sua edição. Igualmente, impende consignar que mesmo antes da súmula vinculante o legislador vinha reconhecendo, cada vez mais, a força da jurisprudência predominante, sumulada ou não ${ }^{185}$.

Ademais, o STF representa a última instância decisória da jurisdição constitucional brasileira. A obediência às súmulas representa a obediência ao entendimento exposto pelo STF. Nessa senda, sustentar a absoluta liberdade interpretativa da Constituição, por parte dos diversos órgãos judiciais do país, significaria conceber um sistema de jurisdição constitucional sem um órgão responsável por sua "uniformização", o que implicaria uma situação de insegurança e instabilidade jurídicas.

A súmula vinculante pode ainda melhorar o judiciário como um todo, e não apenas o STF. É certo que há riscos de distorção indesejada na aplicação da súmula vinculante e da repercussão geral, e que, em certos casos, já se verificaram tais distorções. Contudo, igualmente, não se pode negar o contributo do instituto da súmula vinculante para a formação de um sistema dotado de maior previsibilidade, finalidade que se atribui ao direito, sobretudo em vista das divergentes decisões sobre temas

184 Além dos legitimados artigos para provocar o STF para criar, rever ou cancelar súmula vinculante é possível contar com a contribuição de outras pessoas, órgãos, entidades (animus curiae), que poderão fornecer novos subsídios para o deslinde da questão jurídica no debate.

$185 \mathrm{O}$ art. 38 da Lei $\mathrm{n}^{\circ}$ 8.038/90 atribuiu poderes ao relator de recursos ajuizados perante o STF e STJ para negar seguimento aos que contrariassem jurisprudência desses Tribunais nas questões predominantemente de direito. Cuida-se da conhecida súmula impeditiva de recursos. No âmbito da administração pública federal, o art. $4^{\circ}$ da Lei n ${ }^{\circ} 9.469 / 97$, permitiu ao Advogado-Geral da União dispensar a propositura de ações e recursos, quando a questão já estiver sendo iterativamente decidida pelo Supremo Tribunal Federal ou pelos Tribunais Superiores. A Lei no 9.756/98 alterou ainda a redação do artigo 557 do Código de Processo Civil, bem como acresceu ao dispositivo os $\S \S 1^{\circ}$-A e $2^{\circ}$, ampliando significativamente os poderes de relator de recurso. 
largamente debatidos. A súmula vinculante alcança ainda a administração pública, maior usuária do sistema judicial, que muitas vezes litiga sobre questões de direitos fundamentais já reconhecidos pelo STF.

\section{Conclusões}

As funções realizadas pelo STF extrapolam o âmbito jurisdicional-constitucional e abrangem também questões claramente administrativas. A tênue separação entre função jurisdicional e função administrativa reforça a necessidade de harmonia entre todas as funções da justiça.

O STF deve estar atento às transformações políticas, sociais, culturais, ambientais e aos novos saberes. A interdisciplinariedade e a aplicação de modernos métodos de gestão nos assuntos públicos, influenciadas pelas noções de boa governância, devem ser captadas e inseridas no debate para a nova compreensão do modelo de justiça. Ainda, é preciso convergir esforços para a integração coerente do sistema judicial estatal com as novas formas de resolução de conflitos e os tribunais supranacionais.

Em termos constitucionais, o grande desafio do STF será assegurar, simultaneamente, direitos fundamentais individuais e coletivos dentro de um contexto de reconhecimento de universalidades distintas, sob a pressão da afirmação do local e do global. No âmbito da administração da justiça, com sensíveis repercussões na seara jurisdicional, as ações requerem a convergência das boas práticas orientadas por transparência, responsabilidade, participação, coerência, eficácia e eficiência.

Desse modo, os aprimoramentos das funções da justiça desempenhadas pelo STF podem se refletir de imediato no desempenho do Tribunal e de todas as esferas do poder judiciário brasileiro, principalmente no que respeita à excelência da prestação jurisdicional e à garantia dos direitos fundamentais.

\section{REFERÊNCIAS}

ADLER, Michael. Tribunal Reform: proportionate dispute resolution and the pursuit of administrative justice. The modern Law Review Limited. 2006.

ALESINA, Alberto; GIAVAZZI, Francesco. O futuro da Europa, reforma ou declínio. Lisboa: Edições 70. 2007.

ALLARD, Julie; GARAPON, Antoine. Les Juges dans la Mondilisation. La nouville revólution du droit. Paris: Le Seuil. 2005.

ALTER, Karen J. Establishing the supremacy of European Law. The making of an international rule of law in Europe. Oxford: Oxford University Press. 2001.

ALTER, Karen J. Private litigants and the new international courts. Comparative 
Political Studies. no 39. 2006.

ARAGÃO, Alexandra. A governância na Constituição Europeia: uma oportunidade perdida? In. Colóquio ibérico: Constituição Europeia - homenagem ao doutor Francisco Lucas Pires. Coimbra: Coimbra Editora. 2005.

BELL, John. Droit Constitutionnel ètranger. L'actualité constitutionnelle dans les pays de commow law et de droit mixte (janvier-juin 2002), Canada, Royaume-Uni. Revue française de droit constututinnelle. $\mathrm{n}^{\circ}$ 53. 2003.

BOGASON, Peter; MUSSO, Juliet A. The Democratic Prospects of Network Governance. American Review of Public Administration. $\mathrm{n}^{\circ}$ 36. 2006.

BORAINE, Alex. Transitional Justice. In: Making States Work. State failure and the crisis of governance. CHESTERMAN, Simon; IGNATIEFF, Michael; THAKUR, Ramesh (orgs.). United Nations University. 2005.

CALLEJÓN, Francisco Balaguer. Niveaux el techniques internes et internationaux des droits en Europe. Une perspective constitutionnelle. Revue française de droit constitutinnelle. $\mathrm{n}^{\mathrm{o}}$ 60. 2004.

CANOTILHO, J. J. Gomes. Brancosos e interconstitucionalidade: itinerários dos discursos sobre a historicidade constitucional. Coimbra: Almedina, 2006.

CANOTILHO, J. J. Gomes. Direito Constitucional e teoria da Constituição. $7^{\mathrm{a}}$ ed. Coimbra: Almedina. 2003.

CANOTILHO, J. J. Gomes. O tempo curvo de uma carta (fundamental) ou direito constitucional interiorizado. Porto: Conselho Distrital do Porto da Ordem dos Advogados. 2008.

CICHOWSKI, Rachel A. Courts, Democracy and Governance. Comparative Political Studies. n 39. 2006.

CICHOWSKI, Rachel; SWEET, Alec Stone. Participation, representative democracy and the courts. In: Democracy transformed? Expanding political opportunities in advanced industrial democracies. B. Cain; R. Dalton; S. Scarrow (eds). Oxford: Oxford University Press. 2003.

COSTA, Flávio Dino de Castro. O Conselho Nacional de Justiça: competências e aspectos processuais. In: Direito e administração da justiça. Vladimir Passos de Freitas e Dario Almeida Passos de Freitas (orgs.). Curitiba: Editora Juruá. 2006. 77-95.

DUFFY, Aurélie. Droit Constitutionnel étranger. L'actualité constitutionnelle dans les pays de commow law et de droit mixte. Royaume-Uni. Revue française de droit constututinnelle. $\mathrm{n}^{\mathrm{o}} 66.2006$.

FAIRBAIRN, Catherine; BROADBRIDGE, Sally. Constitutional Reform Bill [HL]: a Supreme Court for the United Kingdom and judicial appointments. House of Com- 
mons Library. Research paper 05/06. 2005. Disponível em: http://www.parliament. uk/commons/lib/research/rp2005/rp05-006.pdf.

GARAPON, Antoine. Les juges. Un pouvoir irresponsable? Paris: Nicolas Philippe. 2003.

GIESEN, Klaus-Gerd. The post-national constellation: Habermas and "the second modernity". Res Public. A journal of legal and social philosophy. n 10, 2004.

GRABER, Mark. A. The non-majority difficulty. Legislative difference to the judiciary. Studies in American. Political Development, 7. 1993.

HABERLE, Peter. Zeit und Verfassung, In: Probleme der Verfassungsinterpretation, 1976, 312-313, apud MENDES, Gilmar Ferreira; PFLUG, S. M. Passado e futuro da súmula vinculante: considerações à luz da Emenda Constitucional n. 45/04. In: Reforma do Judiciário. RENAULT, Sérgio Rabello Tamm; BOTTINI, Pierpalo (orgs.). São Paulo: Saraiva. 2005.

HOUGUE, C. Beausse. Un aspect des réformes constitutionnelles au Royaume-Uni: La disparition du Lord Chancelier. D'une Constitution non écrite vers une constitution écrite? Revue française de droit constututinnelle. $\mathrm{n}^{\circ}$ 62. 2005. KISKIS, Mindaugas; PETRAUSKAS, Remantas. ICT. Adoption in the Judiciary: Classifying of Judicial Information. International Review of Law Computers \& Technology. 2004.

KOENIG-ARCHIBUGI, Mathias. Mapping Global Governance. In: Governing Globalization. Power, authority and global governance. HELD, David; McGREW, Anthony (orgs.). Cambridge: Polity Press, 2005.

LAKE, David A.; KAHLER, Miles. Governance in a Global Economy. Political Authority in Transition. Woodstock: Princeton University Press, 2003.

LEITE, Glauco Salomão. Súmula vinculante e jurisdição constitucional brasileira. Rio de Janeiro: Forense. 2007.

LOVELL, George. Legislative deferrals: Statutory ambiguity, judicial power, and American democracy. New York: Cambridge University Press. 2003.

MAYNTZ, Renate. La teoria della governance: sfide e prospettive. Rivista Italiana di Scienza Política. n 1.1999.

PEDROSO, João. Percurso(s) da(s) reforma(s) da administração da justiça - uma nova relação entre o judicial e o não judicial. Oficina do Centro de Estudos Sociais. $\mathrm{n}^{\mathrm{o}} 171.2002$.

PICARD, Cheryl A.; SAUNDERS, R. P. The regulation of mediation. In: Law, regulation and governance. NEIL, Michael Mac; SARGENT, Neil C.; Swan, Peter (eds.). Ontário: Oxford university press. 2002.

QUEIROZ, Cristina. Interpretação constitucional e poder judicial: sobre a episte- 
mologia da construção constitucional. Coimbra: Coimbra Editora. 2000.

RICHARDSON, Genevra; GENN, Hazel. Tribunals in transition: resolution or adjudication. Public Law. Spring, 2007.

ROCHA, Carmen Lúcia Antunes. Sobre a súmula vinculante. Revista de Informação Legislativa. $\mathrm{n}^{\mathrm{o}}$ 133. 1997.

ROSENAU, James N. Governance in a New Global Order. In: Governing Globalization. Power, authority and global governance. HELD, David; McGREW, Anthony (eds.). Cambridge: Polity Press, 2005.

SAND, Inger-Johanne. Polycontextuality as an alternative to constitutionalism. In: Transnational Governance and Constitutionalism. Christian Joerges, Inger-Johanne Sand and Gunther Teubner (eds.). Oxford and Portland Oregon: Hart Publishing, 2004.

SARGENT, Neil C. Is there any justice in alternative justice? In: Law, regulation and governance. NEIL, Michael Mac; SARGENT, Neil C.; Swan, Peter (eds.). Ontário: Oxford university press. 2002.

SENARCLENS, Pierre de. Mondialization, Souveraineté et Théories des Relations Internationales. Paris: Armand Colin. 1998.

SLAUGHTER, Anne-Marie. A global community of courts. Havard International Law Journal, n 44.2003.

STARCK, Christian. Jurisdiccion Constitucional y tribunales ordinarios. Revista Española de Derecho Constitucional. $\mathrm{n}^{\circ}$ 53. 1998.

SWEET, Alec Stone. The Judicial Constrution of Europe. Oxford: Oxford University Press. 2004.

SWEET, Alec Stone. The Juridical Coup d'État and the Problem of Authority. German Law Journal. v. 8, $\mathrm{n}^{\circ}$ 10. 2007.

SWEET, Alec Stone; BRUNELL, Tom. Constructing a Supranational Constitution: Dispute resolution and governance in the European Community. American Political Science Review. no 92.1998.

VELLOSO, Carlos Mário da Silva. Do poder judiciário: como torná-lo mais ágil e dinâmico. Efeito vinculante e outros temas. Revista de Informação Legislativa. $\mathrm{n}^{\mathrm{o}}$ 138. Brasília. 1998.

WAHL, Rainer; WIELAND, Joachim. La jurisdiccion constitucional como bien escaso el acesso al bundesverfassungsgerichtI. Revista Española de Derecho Constitucional. $\mathrm{n}^{\circ}$ 5. 1997.

WOODS, Ngaire. Global Governance and the role of institutions. In: Governing 
Globalization. Power, authority and global governance. HELD, David; McGREW, Anthony (eds.). Cambridge: Polity Press. 2005.

ZUCKERMAN, Adrian A. S. Civil Justice in Crisis - Comparative Perspectives of Civil Procedure. Oxford: Oxford University Press. 1999. 